\title{
The immunofluorescence techniques in the diagnosis of endocrine autoimmune diseases
}

\author{
Corrado Betterle $\cdot$ Renato Zanchetta
}

Received: 3 April 2012/Accepted: 5 May 2012/Published online: 6 June 2012

(C) Springer-Verlag 2012

\begin{abstract}
In the study of autoimmune diseases, the laboratory plays a very important role. We describe the immunofluorescence techniques (direct, indirect, complement-fixing, double) for determining the presence of autoantibodies and their role in the autoimmune endocrine diseases.
\end{abstract}

Keywords Immunofluorescence techniques .

Autoimmune diseases - Thyroid · Gastric - Adrenal .

Parathyroid · Gonadal · Pancreatic · Pituitary

\section{Introduction}

In the study of autoimmune diseases, the laboratory plays a very important role in predicting or detecting, by immunological studies, the reactions between antigens (Ags) and antibodies (Abs).

Many researchers applied these techniques, year after year more sophisticated and accurate as reported by Betterle [1], for detecting the presence of autoantibodies in patients affected by the autoimmune diseases.

The main analytical techniques used in clinical immunology's laboratories may be summarized in Table 1 .

\section{Immuno-histochemical and immuno-enzymatic techniques}

Antigen-antibody interactions

The key reactions of immunology and immune defense are the interaction of Abs and Ags forming large irreversible

C. Betterle $(\bowtie) \cdot$ R. Zanchetta

Department of Medicine (DIMED), University of Padua Medical

School, Via Ospedale Civile 105, 35128 Padua, Italy

e-mail: corrado.betterle@unipd.it macromolecule complexes. These interactions, analogous to those observed in enzyme-substrate interactions, involve non-covalent binding of antigenic determinants.

In research, purified antibodies (monoclonal or polyclonal) are most commonly used to identify and locate intracellular and extracellular proteins or autoantibodies present in body fluids or attached to some cellular or tissue antigens. Antibodies are used in flow cytometry, immunoprecipitation [2], Western blot analyses [3] and in immunohistochemistry or immunofluorescence (IF) [1] to examine the protein expression in tissue sections or to locate proteins within cells.

Some general characteristics of the laboratory's techniques (accuracy, precision, linearity, sensitivity, specificity and plausibility) must be applied also to the immunofluorescence techniques. This is an important point, because sometimes it is not easy to find all these parameters simultaneously present in the same test because for e.g., the sensitivity is not always in accord with the specificity. It is certainly difficult to find equilibrium between these parameters but this must be the purpose both the implementation of the various tests and international standardization studies.

Some other parameters (preparation of substrates, solutions buffers, fixation and others) [4] may play an important role in the immunofluorescence studies: in the past, the laboratory's techniques were entrusted to the skill and dexterity of the technicians, today there are many companies specialized in the preparation of substrates for immunohistochemistry.

Today, the technical procedures have changed significantly because the previous manual techniques have been replaced by automated systems. But today only the visual check by microscope is left to the experience of the technician who reads the reaction. 
Table 1 Analytical techniques used in the autoimmunity laboratory

\begin{tabular}{l} 
Agglutination \\
Immunoprecipitation \\
Turbidimetry \\
Nephelometry \\
Double immunodiffusion \\
Counterimmunoelectrophoresis \\
Immunofluorescence \\
Immunoassays \\
ELISA \\
IRMA \\
Immunoblot \\
Western blot \\
Dot blot \\
\hline
\end{tabular}

Immunofluorescence techniques

The immunofluorescence is a histochemical laboratory staining technique that uses the specificity of Abs to their antigen. It is a widely used in immunohistochemistry based on the use of some fluorochromes [5] to visualize the location of the Abs.

The immunofluorescence technique was firstly described in 1942 and refined by Coons in 1950, which used a fluorescence microscope able to read the specific immunological reaction on tissue or cellular prepared on slides. Subsequently, in 1963, granular deposits of IgG and C3 were described along the dermo-epidermal junction in lesions of lupus erythematosus. In 1964, Beutner [6] used the indirect immunofluorescence (IIF) technique to demonstrate antibodies in the sera of patients affected by pemphigus and, in the same years, this technique was used to detect the most important autoantibodies in endocrine autoimmune diseases (see below).

There are four major IF techniques:

1. Direct immunofluorescence technique: it is a one-step histological staining procedure for identifying in vivo antibodies that are bound to tissue antigens, using a single antibody labeled with a fluorophore [5] for staining the tissues or cells. The antibody recognizes the target molecule and binds to it.

2. Indirect immunofluorescence technique: it is a twostep serological technique for the detection of circulating antibodies in body fluids, using two antibodies. The unlabeled first (primary) antibody specifically binds the target molecule, and the secondary antibody, which carries the fluorophore, recognizes the primary antibody and binds to it.

3. Indirect immunofluorescence complement-fixation (IIF-CF) technique: Ags and Abs bind to one another to generate many molecules of $\mathrm{C} 3$. This amplification principle is used in complement IIF, which is more sensitive than IIF.

4. Double immunofluorescence technique: this technique allows identifying the presence of two different antigens on a cell or for the identification of specific cell in a tissue by two antibodies labeled with different fluorophores (for es. FITC or rhodamine). Double staining can be used as a direct/indirect method. The indirect method has very high sensitivity.

\section{Historical features in autoimmune diseases of the endocrine glands}

The ante litteram description of the autoimmune nature of the endocrine glands goes back to 1855, when Addison [7] described a case with adrenal insufficiency due to an idiopathic (lymphocytic) infiltration of the adrenals; and to 1912, when Hashimoto [8] described mononuclear leukocyte infiltration with an enlarged thyroid gland in patients, defining it as "lymphomatous goiter" and to 1940, when Von Mayerburg [9] described a lymphocytic infiltration of pancreatic islets (insulitis) in patients with type 1 diabetes mellitus. In 1956, three important discoveries were reported permitting the start of the era of autoimmune diseases: (a) the demonstration of autoantibodies against thyroglobulin in chronic thyroiditis [10], (b) the presence of an agent stimulating the thyroid in patients with Graves' disease [11] and (c) the demonstration that chronic thyroiditis was reproducible in rabbits by immunization with homogenates of autologous thyroid tissue [12]. In 1957, Witebsky [13] established the criteria for defining an autoimmune disease summarized in Table 2.

In the 1957, it was discovered that "idiopathic" Addison's disease (AD) had complement fixing autoantibodies against adrenal cortex extracts [14]. On 1962, antibodies to parietal cells were identified by complement fixation test in patients with pernicious anemia [15]. In the 1968, antibodies to steroid-producing cells were described by IIF technique in patients with gonadal failure [16]. On 1974, the autoimmune nature of type 1 diabetes mellitus was firstly described by IIF when islet cells autoantibodies were demonstrated [17].

On the basis of these discoveries from 1956 to 2006, a progressively increased number of diseases previously

Table 2 Criteria for defining a disease as autoimmune (modified from Witebsky [13])

Presence of autoantibodies and/or cell-mediated events in the serum Presence of lympho-monocyte infiltration in the target organs Possibility of identification and isolation of autoantigens

Possibility of experimentally induction of the disease in animals by immunization with autoantigens and the transfer the disease passively by serum or lymphocytes 
considered as idiopathic, entered in this new group of disorders, so that in 2006 in the preface of the book that celebrated the 50th Anniversary of the discovery of autoimmunity, Rose and Mackey affirmed that "more than 80 diseases are attributable to autoimmunity and one or another affect some $7 \%$ of the population" [18].

\section{Natural history of endocrine autoimmune diseases}

The autoimmune endocrine diseases are chronic disorders characterized by genetic predisposition, presence of circulating autoantibodies and lymphocytic infiltration in the target organs and the natural history of these diseases develops in three separate phases: (a) potential, (b) subclinical or latent, and (c) clinical. Autoantibodies are the circulating markers that encompassed all the three phases. On the basis of their ability to induce or not a damage of target organ, the autoantibodies can be subdivided as pathogenetic and non-pathogenetic [19].

\section{Autoantibodies in autoimmune endocrine diseases}

The endocrine system is one of the systems more affected by autoimmunity. The main autoimmune diseases of the endocrine system are summarized in the Table 3.

Table 3 Autoimmune endocrine diseases

Thyroid diseases
Chronic thyroiditis
Graves' disease
Endocrine ophthalmopathy
Gastric diseases
Autoimmune gastritis
Pernicious anemia
Adrenal diseases
Addison's disease
Adrenal medullitis
Gonadal diseases
Ovarian insufficiency
Male infertility
Chronic hypoparathyroidism
Pancreatic diseases
Type I diabetes mellitus
Flier syndrome
Hirata syndrome
Pituitary diseases
Lymphocytic adenohypophysitis
Infundibuloneurohypophysitis
Polyendocrine syndromes Type I, II, III, IV

Thyroid autoimmune diseases

Thyroid autoimmune diseases (TAD) are summarized in Table 3. They are marked by the presence of thyroglobulin autoantibodies (TGAbs) and thyroid microsomal autoantibodies (TMAbs).

TGAb were initially detected by immunoprecipitation in agar [10] and then by IIF technique on thyroid sections fixed in methanol [20]. On 1961, they were detected by passive hemoagglutination using sheep red cells [21] and on 1978 using turkey-nucleated red cells [22]. In 1974, TGAbs were tested by RIA [23, 24] and, in 1980, by ELISA [25, 26], nevertheless for a long period TGAbs were tested using IIF on unfixed thyroid tissue (Fig. 1).

TMAbs were detected, since 1967 , by IIF on unfixed thyroid tissue [20], and from 1973 also by passive hemoagglutination using sheep red cells [27], and from 1976 using or turkey-nucleated red cells [28]. They were tested by RIA or ELISA using microsomal antigens [29, 30].

By IIF or hemoagglutination techniques the TGAbs and TMAbs were found in 85-95\% of patients with chronic thyroiditis and in $85 \%$ of patients with Graves' disease [26-28].

After the discovery on 1985, thyroperoxidase (TPO) is the target antigen [31] recognized by TMAbs, antibodies to TPO (TPOAbs) were detected by RIA $[32,33]$ or ELISA [34] using recombinant antigens.

These methods are a slightly more sensitive and specific than the previous tests [35], nevertheless, the IIF test on unfixed thyroid tissue was used for many years after.

TGAbs and/or TMAbs/TPOAbs were also present in $50 \%$ of first-degree relatives of patients with autoimmune thyroid diseases, in 15-40\% of patients with other autoimmune diseases and they can also be found in $20 \%$ of patients with thyroid carcinoma [26]. These auto-Abs can be found in 12-26\% of euthyroid females and in 2.8-14.4\% of euthyroid males [36]. The presence of these autoAbs was considered a marker of future thyroid dysfunction [37, 38].

The IIF test on thyroid tissue in addition to the detection of TMAbs and TGAbs permitted also to individuate others autoantibodies (such as mitrochondria antibodies AMA and anti-nuclear antibodies ANA) (Fig. 1e, f).

Gastric autoimmune diseases

The gastric autoimmune diseases are summarized in Table 3. The diseases are marked by the presence of parietal cells autoantibodies (PCA). Initially, PCA were detected by complement fixation test using homogenates of stomach $[39,40]$ and were found in $62 \%$ of patients with pernicious anemia and in $4 \%$ of normal controls. Subsequently they were detected by IIF using human or animal gastric mucosa; 


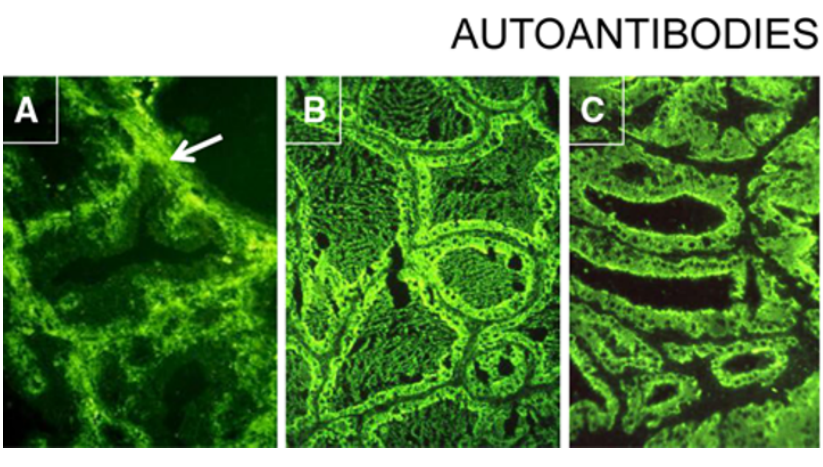

Fig. 1 Indirect IF on unfixed thyroid tissue. a Pattern produced by a normal serum: the cytoplasm of thyrocites and the thyroglobulin inside the follicles are negative, the fluorescence is concentrated in the connective tissue between the thyroid follicles (arrow). b Pattern produced by a serum of a patient with high titers of TMA and TgAbs: the cytoplasm of the thyrocites is diffusely and intensively stained and the substance inside the follicles is also intensively stained. c Pattern produced by a serum of a patient with high titers of TMA: the cytoplasm of the thyrocites is diffusely and intensively stained and the substance inside the follicles is negative. d Pattern produced by a

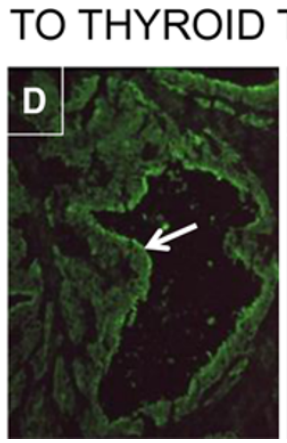

TISSUE
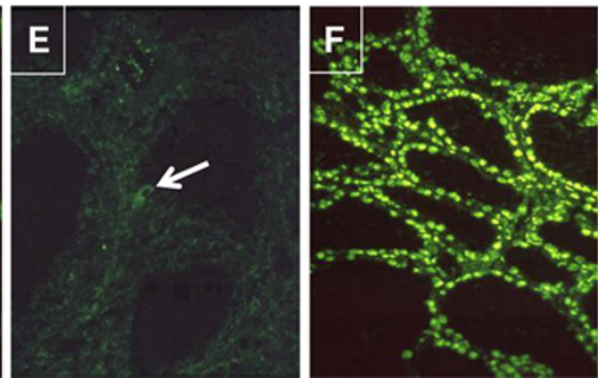

serum of a patient with low titers of TMA: a weak positivity is present in the cytoplasm of thyrocites with reaction in the apical rim of thyrocites where the microsomal antigen is concentrated (arrow). e Pattern produced by a serum of a patient with high titers of mitochondria Abs: the serum shows a granular pattern of cytoplasm of thyrocites and the reaction is concentrated in scattered cells rich in mitochondria (see arrow). f Pattern produced by a serum of a patient with high titers of anti-nuclear Abs: the reaction is positive on the nuclei of thyrocites
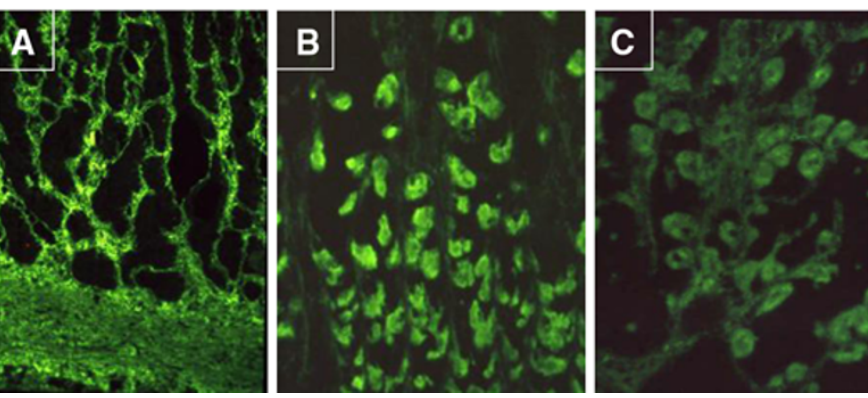

Fig. 2 Indirect IF on human unfixed gastric mucosa. a Pattern produced by a normal serum: the cells in the glands of the stomach are negative, the fluorescence is concentrated in the connective tissue. b Pattern produced by a serum of a patient with high titers of PCA: the reaction is positive with a diffuse pattern of cytoplasm of the cells scattered in the glands (parietal cells), while the chief cells are negative. $\mathbf{c}$ Pattern produced by a serum of a patient with low titers of PCA: the serum reacts as a diffuse pattern on the cytoplasm of the cells scattered in the glands (parietal cells), while the chief cells are negative. d Pattern produced by a serum of a patient with high titers of mitochondria Abs: the serum reacts to the parietal cells (rich in

with this technique, PCA were found in $86 \%$ of patients with pernicious anemia and in $11 \%$ of controls [40]. PCA are organ, but not strictly species-specific auto-Abs of IgG class, reacting with the microsomal fraction of parietal cells [40] (Fig. 2). On 1984, a RIA was introduced using microsomal gastric antigen in order to detect PCA [41].

On 1987, ATPasi $\mathrm{H}^{+} / \mathrm{K}^{+}$was identified as the target antigen detected by PCA and an ELISA was produced to detect $\mathrm{ATPasiH}{ }^{+} / \mathrm{K}^{+} \mathrm{Abs}$ and with this method were found in $88 \%$ of patients with chronic gastritis [42]. PCA can be found in normal population with a frequency that increases with the age, in fact they are present in $4.8 \%$ in subjects mitochondria) (pink arrow) with a major intensity and weakly the cytoplasm of chief cells having a minor concentration of mitochondria. e Pattern produced by a serum of a patient with high titers of anti-ribosomal Abs: the serum stains intensively the cytoplasm of the chief cells but it does not react with the cytoplasm of parietal cells (red arrow). f Pattern produced by a serum of a patient with high titers of anti-nuclear Abs: the serum stains the nuclei of all the cells of the gastric mucosa. In this case some nuclei show an aspect of comet (white arrow) (this pattern is indicative of antibody to double strained DNA)

under 50 years but reached $9.6 \%$ in those with more than 80 years [43]. PCA are also present in $5-25 \%$ of the patients with other autoimmune diseases, particularly in those with thyroid autoimmune diseases, Addison's disease, type 1 diabetes or vitiligo [42, 44]. PCA can be found in asymptomatic patients and they can be considered markers of latent autoimmune gastritis [45] or predictors of future autoimmune gastritis [46]. Until today, the IIF test on gastric tissue is already the most used to detect PCA.

The IIF test on gastric mucosa is able to detect also other auto-Abs such as ANA, AMA, ribosomal antibodies (ARA) and smooth muscle antibodies (SMA) (Fig. 2d-f). 
Autoimmune diseases of the endocrine pancreas

The autoimmune diseases of the endocrine pancreas are summarized in Table 3. Islet-cell autoantibodies (ICA) were discovered on 1974 by IIF test using normal human group 0 pancreas [17]. They react with an unidentified antigen common to all the cells of the pancreatic islets (Fig. 3b). They are of IgG class, able to fix the complement, organ- but not strictly species-specific because they can react also with primate pancreas. On 1985 under the aegis

\section{AUTOANTIBODIES TO PANCREATIC TISSUE}
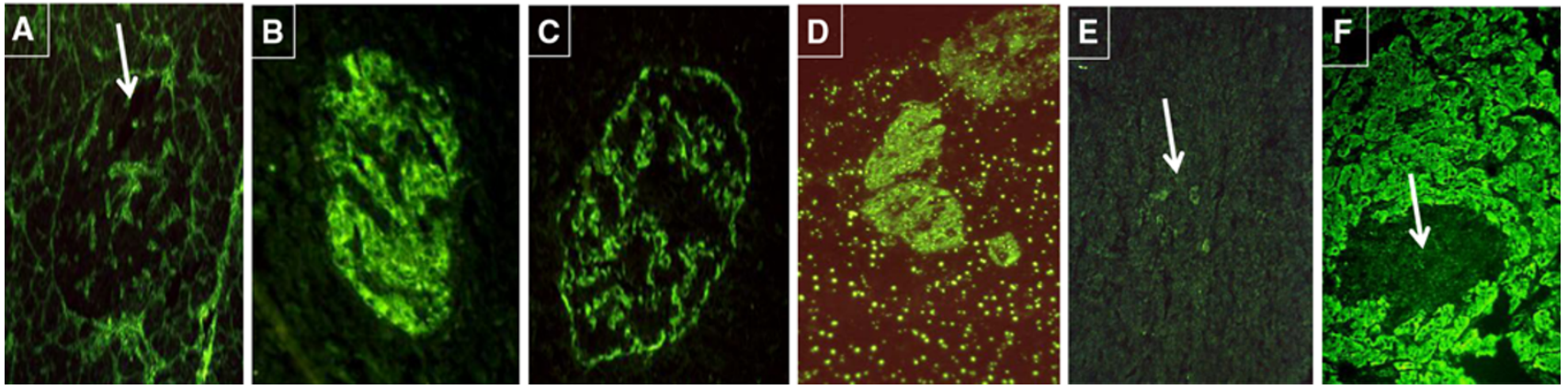

Fig. 3 Indirect IF on human unfixed pancreas. a Pattern produced by a normal serum: the cells of the islet are negative (arrow), the fluorescence is concentrated in the connective tissue inside and outside the islet. b Pattern produced by a serum of a patient with high titers of ICA: the positivity is present on cytoplasm of all the isletcells, while the capillaries inside the islets are negative. c Pattern produced by a serum of a patient with antibodies to separate cells of the islet: the serum stains with a great intensity the cytoplasm of cells scattered in the islet. d Pattern produced by the serum of a patient

with high titers of ICA and of anti-nuclear Abs: the serum stains intensively the cytoplasm of the islet-cell and the nucleoli of all the cells inside and outside the islet (nucleolus pattern). e Pattern produced by a serum of a patient with high titers of mitochondria Abs: the serum stains weakly the cytoplasm of all the cells in the exocrine tissue, with a major intensity against some cells (rich in mitochondria) (arrow). f Pattern produced by a serum of a patient with ribosomal autoantibodies: the cytoplasm of the cells of the exocrine tissue is diffusely stained, on the contrary the islet-cells are negative (arrow)

\section{AUTOANTIBODIES TO PANCREATIC TISSUE}
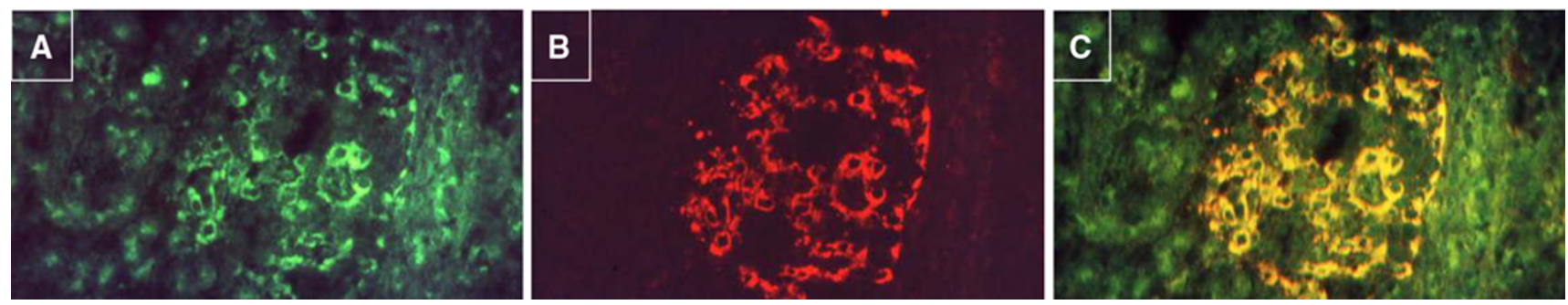

Fig. 4 Double IF on human unfixed pancreas. a Green pattern produced by a serum of a patient counterstained by FITC-labeled goat anti-human serum, the fluorescence is concentrated on the cytoplasm of scattered cells of the islet. b Red pattern produced by an antiglucagon rabbit serum counterstained with a rhodamine-labeled anti- rabbit serum: the rabbit serum stains in red the same cells as the human serum. c The double microphotographic exposure of the images a and $\mathbf{b}$, produces a yellow colour (sum of the green and the yellow) confirming that the human serum reacts against glucagon-producing cells
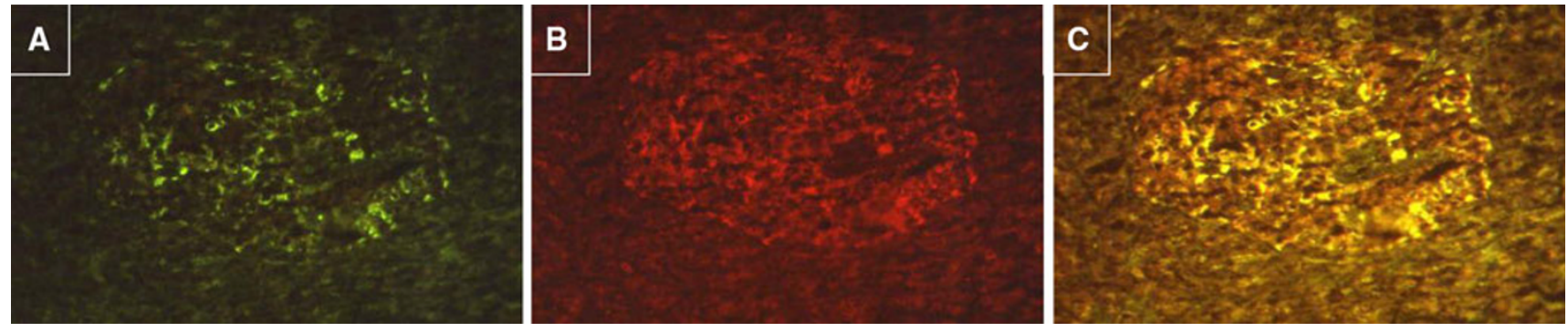

Fig. 5 Double IF on human unfixed pancreas. a Green pattern produced by a serum of a patient counterstained by FITC-labeled goat anti-human serum, the fluorescence is concentrated in the cytoplasm of scattered cells of the islet. b Red pattern produced by an antisomatostatin rabbit serum counterstained with a rhodamine-labelled anti-rabbit serum the rabbit serum stains in red the same cells as the human serum. c The double microphotographic exposure of the images $\mathbf{a}$ and $\mathbf{b}$, produced a yellow colour (sum of green and red) confirming that the human serum reacts against somatostatinproducing cells 
of the Juvenile Diabetes Foundation, a standard positive serum with a value a $80 \mathrm{U} / \mathrm{JDF}$ was identified and the distribution worldwide of this standard serum permitted to improve the sensitivity and specificity of the various laboratories detecting ICA by IIF [47-49]. Subsequently, other pancreatic autoantibodies were identified against insulin (IAA) [50], GAD (GADAb) [51], second islet autoantigen (IA2Ab) also called ICA 512 [52]. The IIF test identified ICA in $48-60 \%$ of newly onset type 1 DM $[53,54]$. ICA can be also present in about $9 \%$ of the patients with type 2 DM [54] and they are able to identify, in combination with GADAb, the latent autoimmune diabetes of the adults (LADA) [55]. ICA associated to other pancreatic Abs can also be identified in individuals without diabetes (first-degree relatives of patients with type $1 \mathrm{DM}$, schoolchildren, or patients with other autoimmune diseases) and they can be markers of future disease with an increased risk directly correlated with the number of pancreatic auto-Abs [56, 57].

Using IIF technique on human pancreas, other reactivities against different cells of the islets were also discovered (Fig. 3c) and identified by the double IF technique as autoantibodies to glucagon-producing cells (GPCAb) (Fig. 4) or to somatostatin-producing cells (SPCAb) (Fig. 5) [58]. But, so far these antibodies were not correlated with a clinical deficiency of these hormones [59].

The determination of ICA in combination with other pancreatic Abs remains, today, the best method for the identification of patients with autoimmune type $1 \mathrm{DM}$, LADA or the subjects at risk of type $1 \mathrm{DM}$.

The IIF test on pancreas identified other reactivities such as AMA, ANA, ARA (Fig. 3d, e) and Abs against cytokeratin.
Autoimmune diseases of the adrenal

The adrenal cortex autoimmune diseases are summarized in Table 3. Adrenal cortex autoantibodies (ACA) are markers of autoimmune adrenal insufficiency and were discovered on 1957 by complement fixation using adrenal cortex extracts [14]. From 1963, they were tested by IIF technique using human or animal tissues [60]. ACA react with the cytoplasm of all the three cells layers of adrenal cortex (Fig. 6b), they are of IgG class, organ, but not strictly species, specific and fix the complement. Using the IIF technique on human or animal adrenal tissues, many patients affected by autoimmune and tuberculous AD were studied, and ACA were found positive in 61 and $6.7 \%$, respectively [61].

In 1992, it was discovered that the enzyme 21-hydroxylase $(21-\mathrm{OH})$ is the major autoantigen recognized by ACA $[62,63]$. After this discovery, a RIA test using ${ }^{35} \mathrm{~S}-21-\mathrm{OH}$ [64] was used to detect 21-OHAbs. Subsequently, a more convenient assay to measure 21-OHAbs has been developed using ${ }^{125} \mathrm{I}-21-\mathrm{OH}$ expressed in yeast [65].

ACA by IIF on human adrenal cortex or 21-OHAbs by IPA are present in 89 and $91 \%$, respectively, of patients at the onset of autoimmune Addison's disease, but absent in patients with non-autoimmune forms. There is a strict correlation between the two methods even if 21-OHAbs are able to detect very low titers of antibodies and ACA can detect some autoantibodies different from 21-OHAbs [66].

They can be present also in individuals without hypoadrenalism and they can predict the future adrenal insufficiency [67]. On 2012, under the aegis of Euradrenal Committee, a program for the standardization of $21-\mathrm{OH}$
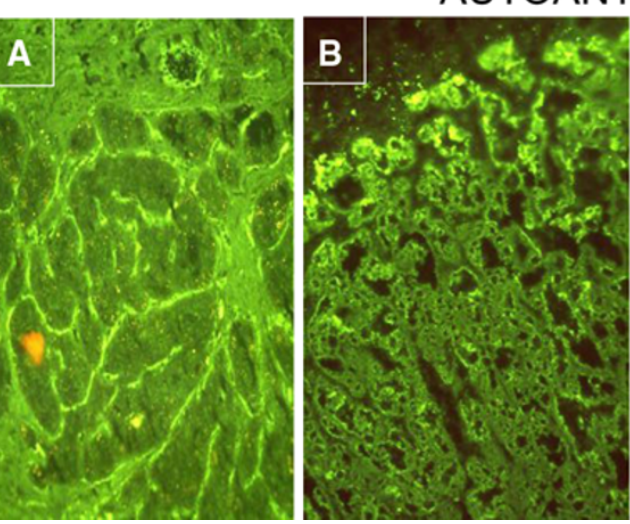

Fig. 6 Indirect IF on human unfixed adrenal tissue. a Pattern produced by a normal serum: the cells of the adrenal cortex are negative, the fluorescence is concentrated in the connective tissue. b Pattern produced by a serum of a patient with high titers of ACA: the reaction is positive on cytoplasm of the cells of all the three layers of the adrenal cortex with a diffuse pattern. $\mathbf{c}$ Pattern produced by a serum of a patient with high titers of ACA: the serum stains the
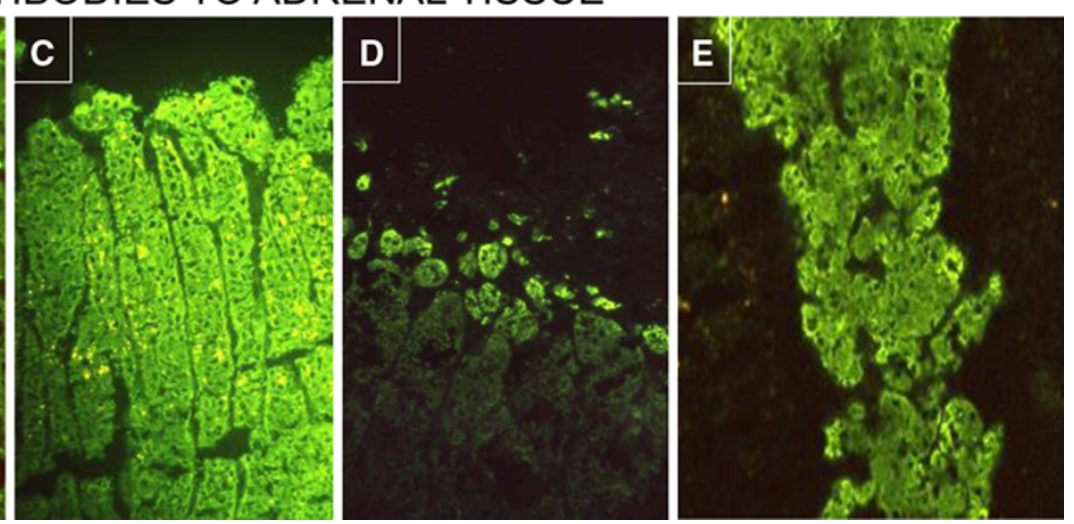

cytoplasm of the cells of the glomerulosa with a diffuse pattern. d Pattern produced by a serum of a patient with low titers of ACA: the serum stains the cytoplasm of the cells of the glomerulosa. e Pattern produced by a serum of a patient with high titers of adrenalmedullary-cell antibody: the serum diffusely stains the cells of the adrenal medulla 


\section{AUTOANTIBODIES TO STEROID-PRODUCING TISSUES}
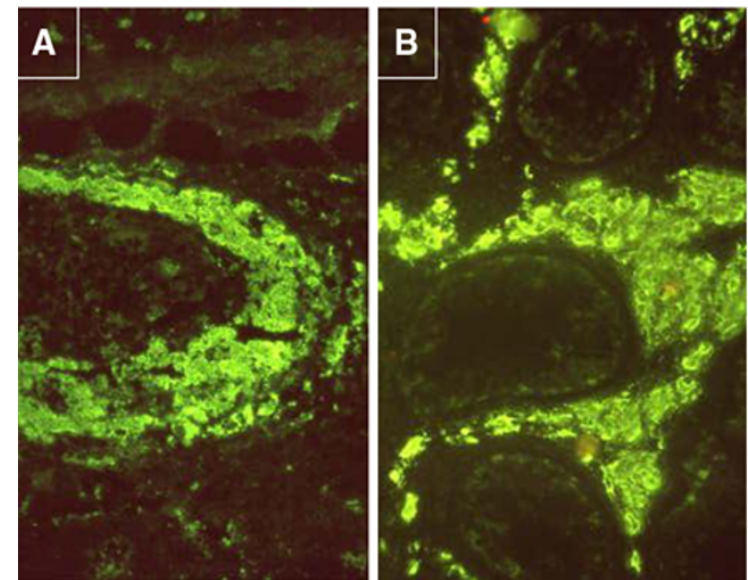

Fig. 7 Indirect IF on human unfixed ovary, testis, placenta and adrenal. Pattern produced by a serum with antibodies to steroidproducing cell: this serum diffusely stains the cytoplasm of the theca

Abs involving multiple international laboratories has been initiated and the results of this study will be published (Betterle personal observation).

\section{Adrenal medulla autoimmunity}

Autoimmune diseases of the adrenal medulla are summarized in Table 3. On 1984, it was described an adrenalmedullary-cell antibody (AMCA) of IgG class, reacting to an unidentified cytoplasmic antigen of adrenal medulla [68]. The AMCA can produce a "diffuse" (Fig. 6) or a "granular" pattern. AMCA are detected in $30 \%$ of ICApositive and $4 \%$ of ICA-negative patients with type $1 \mathrm{DM}$, and in $32 \%$ of ICA-positive patients without type $1 \mathrm{DM}$ [69].

The clinical significance of this Abs is not clear. But it is important to remember that: (a) a deficit of catecholamines has been described in type $1 \mathrm{DM}$ patients with AMCA [70], (b) it has been demonstrated an adrenal medulla fibrosis in type 1 DM with longstanding disease [69], (c) some patients with type $1 \mathrm{DM}$ revealed an insufficient adrenergic response to insulin-induced hypoglycaemia [69]. On the basis of all these data it has been hypothesized that these Abs mark, in type $1 \mathrm{DM}$, a lymphocytic medullitis inducing a deficit of catecholamines [69, 71].

Autoimmune diseases of the gonads

Autoimmune diseases of the gonads are summarized in Table 3. On 1968, an antibody to steroid-producing cells (StCA) was detected by IIF test [16], reacting to the cells of the ovarian theca, to Leydig cells of the testis, syncytiotrophoblast of the placenta and to adrenal cortex cells (Fig. 7).
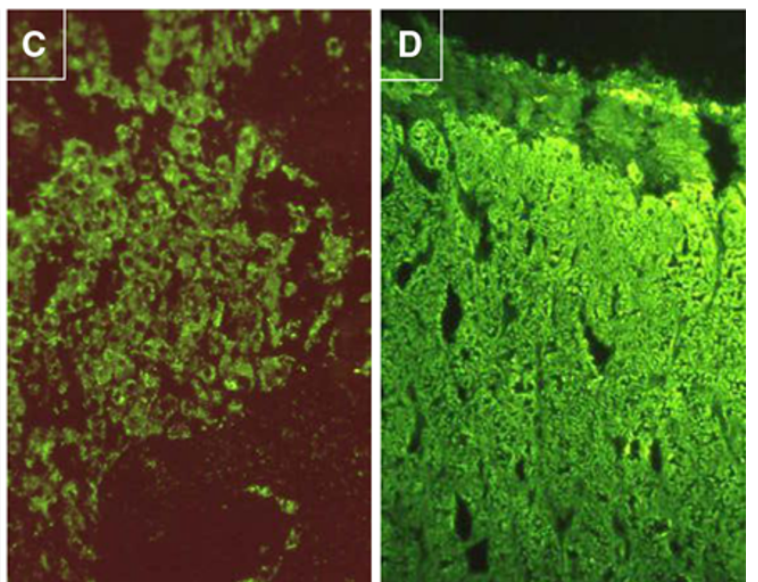

cells of the ovary (a), of the Leydig cells of the testis (b), of the syncytiotrophoblast of placenta (c), and of the adrenal cortex cells (d)

In females affected by Addison's disease, they are markers of premature ovarian failure (POF) [72] characterized by a lymphocytic oophoritis [73]. After the discovery that StCA reacted with steroidogenic enzymes $17 \alpha$-hydroxylase $(17 \alpha-\mathrm{OH})$ or side chain cleavage (SCC) [74], autoantibodies to $17 \alpha-\mathrm{OH}$ (17 $\alpha$-OHAbs) or to SCC (SCCAbs) were tested by a RIA technique, using recombinant antigens [75]. These Abs are present with high frequency (92\%) of Addisonian patients with POF but they are also present in female patients affected by Addison's disease with normal menses and can be predictive markers of future POF [76].

Despite the StCA were initially identified in two male patients affected by Addison's disease [16], it is not clear if in those patients they can be markers of autoimmune testicular insufficiency.

\section{Autoimmune parathyroid diseases}

Parathyroid autoimmune diseases are shown in Table 3. The detection of parathyroid autoantibodies represents one the most problematic and not so far defined cases in autoimmunity. Initially, they were detected in 1966 by IIF using unspecified parathyroid tissue [77], subsequently confirmed with the same method [78]. These autoantibodies reacted to the cytoplasm of the cells of parathyroid tissue (Fig. 8), but they were present with low frequency in chronic hypoparathyroidism $(\mathrm{CH})$, in patients with other autoimmune diseases and also in normal controls [78]. Subsequently, by IIF, autoantibodies reacting with the surface of human parathyroid cells and able to inhibit the PTH secretion or to mediate a complement-dependent cytotoxicity in cultured bovine parathyroid cells were reported in patients with $\mathrm{CH}[79,80]$ but different studies 
Fig. 8 Indirect IF on human unfixed parathyroid tissue. Pattern produced by a serum of a patient with chronic hypoparathyroidism: this serum stains the cytoplasm of cells of parathyroid (a, b). This reaction is not against chief cells of the parathyroid gland but against oxyphil cells rich in mitochondria and it recognizes a human mitochondria antigen of $46 \mathrm{kD}$

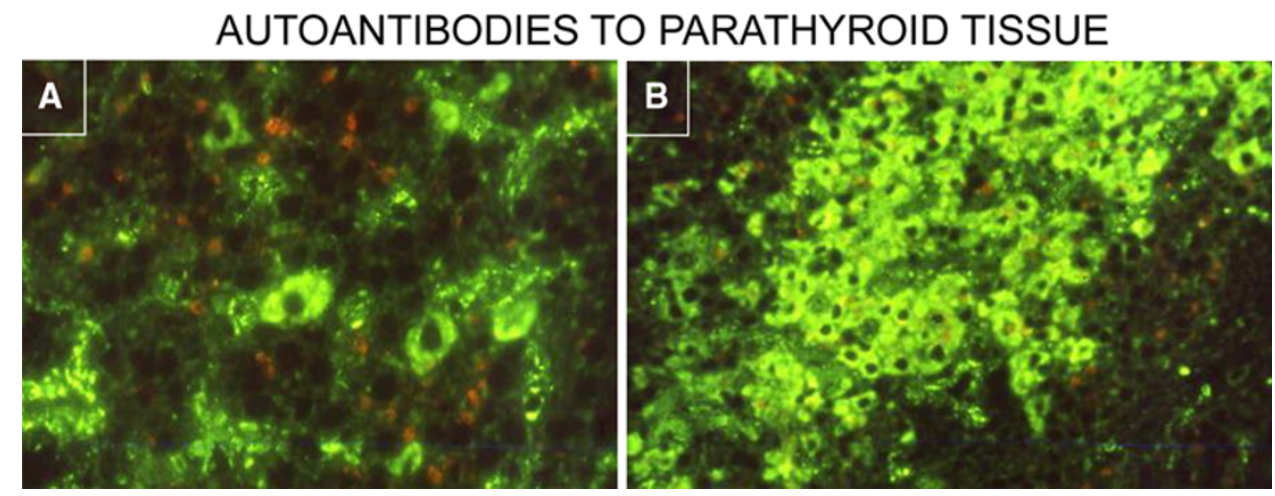

\section{AUTOANTIBODIES TO PITUITARY TISSUE}
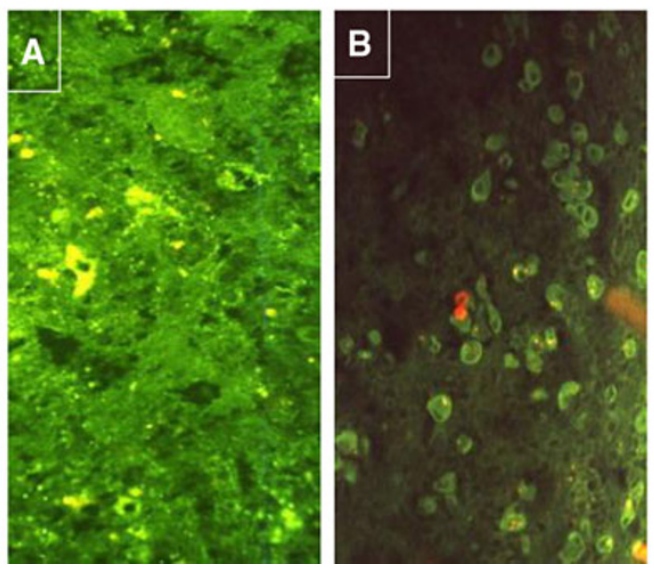

Fig. 9 Indirect IF on human unfixed pituitary. a, b The serum of this patient intensively stains the cytoplasm of some pituitary cells

did not confirm this report [81]. Other studies reported that the parathyroid cytoplasmic antibodies, initially detected by IIF, were reactive only with oxyphil parathyroid cells [82] recognizing a human mitochondrial antigen of $46 \mathrm{kDa}$ molecular weight [83]. Subsequently, autoantibodies against a human parathyroid membraneantigen of $120-40 \mathrm{kDa}$, identified as the calcium sensing receptor (Ca-SR) by immunoblot and Western blotting analysis were identified in $20 \%$ of the patients with $\mathrm{CH}$ (isolated or in the context of autoimmune polyendocrine syndrome type 1) and in $0 \%$ of controls [84]. Subsequently, Ca-SRAbs detected by Western blot, were found in $49 \%$ of the patients with $\mathrm{CH}$ but also in $13 \%$ of the normal controls [85]. In contrast, by immunoprecipitation assay using ${ }^{35} \mathrm{~S}$ labelled recombinant $\mathrm{Ca}-\mathrm{SR}$ antigen, Ca-SRAbs have not been detected in any of 90 patients with $\mathrm{CH}$ [86].

Recently, an antibody to a parathyroid antigen defined NACHT leucine-rich-repeat protein 5 (NALP5Abs) was identified in $48 \%$ of the patients with $\mathrm{CH}$ in the context of autoimmune polyendocrine syndrome type 1 and not in the other forms of $\mathrm{CH}$ or in other autoimmune diseases [87].

Autoimmune pituitary diseases

Autoimmune pituitary diseases are summarized in Table 3. Using human pituitary, the autoantibodies against some pituitary cells permitted to demonstrate, by a double IF technique, a reaction to prolactin-secreting cells [88]. These Abs were described in patients with autoimmune endocrine diseases but in none affected by hypopituitarism [57].

Subsequently, pituitary antibodies were investigated in patients with lymphocytic adenohypophysitis (LAH) by indirect IIF (Fig. 9). Using as substrates human, primate or rodent pituitary specimens, human fetuses, or animal pituitary cell lines, pituitary Abs were found in only $36 \%$ of patients with documented LAH as reviewed by Caturegli [89]. The specificity of pituitary Abs is poor and they were found in various other non-autoimmune diseases as Cushing's syndrome, pituitary adenomas, empty sella syndrome and Sheehan syndrome, as in other autoimmune diseases such as type 1 diabetes, Hashimoto's thyroiditis, and Graves' disease as reviewed by Caturegli [89]. Autoantibodies to a not specified anterior pituitary components were also described in patients with autoimmune diseases and able to predict future hypopituitarism [90]. The biggest problem about the evaluation of these autoantibodies is that do not exist an international standardization of this procedure, furthermore it was documented that the $\mathrm{Fc}$ fragment of immunoglobulins bind to a receptor of ACTH producing cells of the pituitary [91].

As regard to Abs to diencephalon or hypothalamus, initially they were tested by IIF using baboon diencephalon, and antibodies to vasopressin-producing cells were described in $37 \%$ of patients with idiopathic diabetes insipidus [92] (Fig. 10). The specificity of these antibodies is poor being described also in $54 \%$ of patients with DI secondary to histiocytosis $\mathrm{X}$ and in other autoimmune disorders [93]. 


\section{AUTOANTIBODIES TO DIENCEPHALON TISSUE}
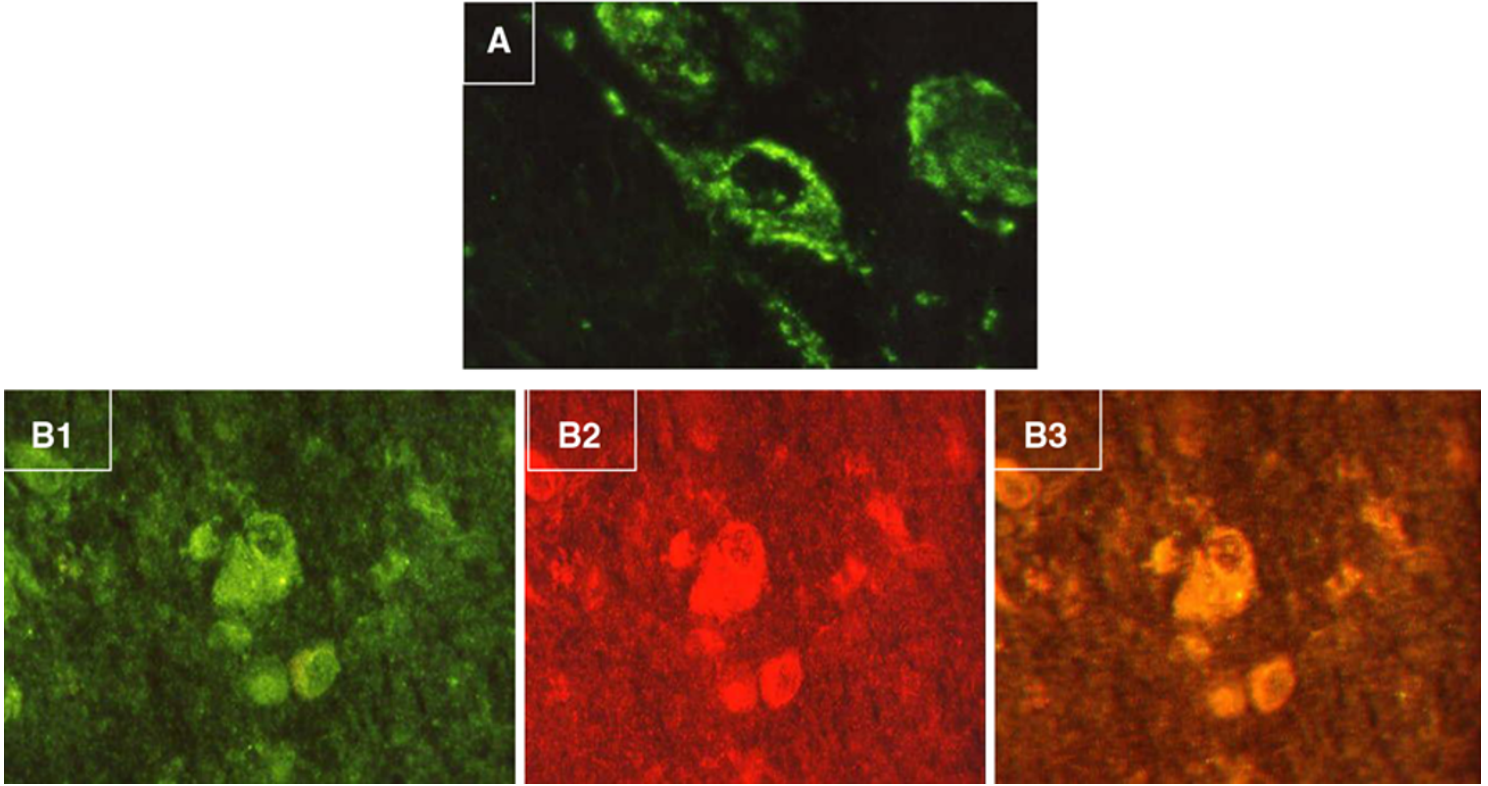

Fig. 10 Double IF on baboom unfixed diencephalon. a Pattern produced by a serum of a patient with diabetes insipidus: some cells of the diencephalon are stained. (from Ref. [1], p. 207, Fig. 7.7). b1 The serum of this patient counterstained by a goat anti-human FITC serum produced a green pattern concentrated in the cytoplasm of some cells. (from Ref. [1], p. 207, Fig. 7.8). b2 A rabbit serum anti-

\section{General conclusion}

Concluding our study and considering that, in these recent years, IF was considered as obsolete and outdate, we think important to report these Mackay's considerations in a recent review on the history of autoimmunity [94]: "in the early 1960s', the immunofluorescence led to the confident nomination of diverse diseases as autoimmune and the technique soon became the laboratory "workhorse" for routine laboratory diagnosis". These words may be valid also today because this technique may be considered very useful in the diagnosis of various organ- and non-organ specific autoimmune diseases.

Acknowledgments This study was supported in part by a grant from the European Union Seventh Framework Programme, the Euradrenal project: Pathophysiology and Natural Course of Autoimmune Adrenal Failure in Europe. Grant Agreement No. 2008-201167 and from Grant ex $60 \%$ of University of Padova. We like to thank Mr. Stefano Masiero for his technical assistance.

Conflict of interest None.

\section{References}

1. Betterle C (1997) Gli Autoanticorpi: Manuale-Atlante a colori di diagnostica. In: Piccin (ed), Padova vasopressin counterstained with an anti-rabbit rhodaminated serum stains in red the same cells stained by the patient's serum. b3 The double microphotographic exposure of the imaging $\mathbf{a}$ and $\mathbf{b}$, produced a yellow colour (sum of green and red) of the cytoplasm of the cells confirming that the human serum reacts against vasopressin-producing cells

2. Williams N (2000) Immunoprecipitation procedures. Methods Cell Biol 62:449-453

3. Kurien B, Scofield R (2006) Western blotting. Methods 38:283-293

4. Scanziani E (1998) Immunohistochemical staining of fixed tissues. Methods Mol Biol 104:133-140

5. Brehm-Stecher B, Johnson E (2004) Single-cell microbiology: tools, technologies, and applications. Microbiol Mol Biol Rev 68:538-559

6. Beutner EH, Jordon R (1964) Demonstration of skin antibodies in sera of pemphigus vulgaris patients by indirect immunofluorescent staining. Proc Soc Exp Biol Med 117:505-510

7. Addison T (1937) Physician to Guy's Hospital. London: New Sydenham Society 1868. Reprinted in Medical Classics 2:244-293

8. Hashimoto H (1912) Zur kenntnis der lymphomatosen veranderung der schilddruse (struma lymphomatosa). Acta Klin Chir 97:219-248

9. Von Mayenburg H (1940) Uber "insulitis" bei diabetes. Schweitz Med Wochenschr 71:554-557

10. Campbell PN, Doniach D, Hudson RV, Roitt IM (1956) Autoantibodies in Hashimoto's disease (lymphadenoid goiter). Lancet 20:820-821

11. Adams DD, Purves HD (1956) Abnormal responses in the assay of thyrotropin. Proc Univ Otago Med School 34:11-12

12. Rose NR, Witebsky E (1956) Studies in organ specificity. V. Changes in the thyroid glands of rabbit following active immunization with rabbit thyroid extracts. J Immunol 76:417-427

13. Witebsky E, Rose NR, Terplan K, Paine JR, Egan RW (1957) Chronic thyroiditis and autoimmunization. JAMA 164:1439-1447

14. Anderson JR, Goudie RB, Gray KG, Timbury GC (1957) Autoantibodies in Addison's disease. Lancet 1:1123-1124 
15. Irvine WJ, Davies SH, Delamore IW, Williams AW (1962) Immunological relationship between pernicious anemia and thyroid diseases. Brit Med J 2:454-456

16. Anderson JR, Goudie RB, Gray KG, Stuart-Smith DA (1968) Immunological features of idiopathic Addison's disease: an antibody to cells producing steroid hormones. Clin Exp Immunol 3:107-117

17. Bottazzo GF, Florin-Christensen A, Doniach D (1974) Islet cell antibodies in diabetes mellitus with autoimmune polyendocrine syndromes. Lancet 2:1279-1282

18. The autoimmune diseases (2006) In: Rose N, MacKay IR (eds) Elsevier, Academic Press, San Diego

19. Betterle C, Presotto F, Pedini B, Greggio N, Accolla R, Zanchetta R (1997) Generalità sulle malattie autoimmuni. In: Betterle C (ed) Gli Autoanticorpi Manuale-Atlante a colori di diagnostica. Piccin, Padova, 1-40

20. Doniach D (1967) Thyroid autoimmune diseases: symposium on thyroid gland. J Clin Pathol 20:385-390

21. Fulthorpe AJ, Roitt IM, Doniach D, Couchman K (1961) A stable sheep cell preparation for detecting thyroglobulin autoantibodies and its clinical application. J Clin Pathol 14:654-660

22. Cayzer I, Chalmers SR, Doniach D, Swana G (1978) An evolution of two new haemoagglutination tests for the rapid diagnosis of autoimmune thyroid diseases. J Clin Pathol 31:1147-1151

23. Salabè GB, Salabe H, Dominici D, Davoli C, Andreoli M (1974) Radioimmunoassay for human antithyroglobulin antibodies. II. Determination of antigen binding capacity. J Clin Endocrinol Metab 39:1125-1132

24. Peake RL, Wills DB, Asimakis GK, Deiss W (1974) Radioimmunological assay for antithyroglobulin antibodies. J Lab Clin Med 84:907-919

25. Voller A, Bidwell DE, Burek CL (1980) An enzyme-linked immunosorbent assay (ELISA) for antibodies to thyroglobulin. Proc Soc Exp Biol Med 163:402-405

26. Endo YE, Junichi N, Horinuchi K, Sachiya O, Motomori I, Ishikawa $E$ (1980) An enzyme immunoassay for the measurement of antithyroglobulin autoantibodies in human serum. Clin Chim Acta 103:67-77

27. Bird T, Stephenson J (1973) Evaluation of a tanned red cell technique for thyroid microsomal antibodies. J Clin Pathol 26:623-627

28. Amino N, Hagen SR, Yamada N, Refetoff S (1976) Measurement of circulating thyroid microsomal antibodies by tanned red cell haemoagglutination technique: its usefulness in the diagnosis of autoimmune thyroid diseases. Clin Endocrinol 5:115-125

29. Mori T, Fisher JP (1971) Measurement by competitive binding radioassay of serum anti-microsomal and anti-thyroglobulin antibodies in Graves' disease and other thyroid disorders. J Clin Endocrinol Metab 33:688-698

30. Scardt CW, McLachlan SM, Matheson J, Rees Smth B (1982) An enzyme linked immunoassay for thyroid microsomal antibodies. J Immunol Meth 55:155-168

31. Czarnocka B, Ruf J, Ferrand M, Carayon P, Lissitzky S (1985) Purification of the human thyroid peroxidase and its identification as the microsomal antigen involved in autoimmune thyroid diseases. FEBS Lett 190:147-152

32. Mariotti S, Anelli S, Ruf J, Bechi R, Czarnocka B, Lombardi A, Carayon P, Pinchera A (1987) Comparison of serum thyroid microsomal and thyroid peroxidase autoantibodies in thyroid diseases. J Clin Endocrinol Metab 65:987-993

33. Ruf J, Czarnocka B, Ferrand M, Doullais F, Carayon P (1988) Novel routine assay of thyroperoxidase autoantibodies. Clin Chem 34:2231-2234

34. Kaufman KD, Filetti S, Seto P, Rapaport B (1990) Recombinant human thyroid peroxidase generated in eukaryotic cells: a source of specific antigen for the immunological assay of antimicrosomal antibodies in the sera of patients with autoimmune thyroid disease. J Clin Endocrinol Metab 70:724-728

35. Mariotti S, Caturegli P, Piccolo P, Barbesino G, Pinchera A (1990) Antithyroid peroxidase autoantibodies in thyroid diseases. J Clin Endocrinol Metab 71:661-669

36. Prummel MF (2005) Thyroid peroxidase autoantibodies in euthyroid subjects. Best Practice Res Clin Endocrinol Metab 19:1-15

37. Vanderpump MPJ, Tunbridge WMG, French JM, Appleton D, Batest D, Clark F, Grimley Evans J, Hasan DM, Rodgers H, Tunbridge F, Young ET (1995) The incidence of thyroid disorders in the community: a twenty-year follow up of the Whickham survey. Clin Endocrinol 43:55-698

38. Walsh JP, Bremner AP, Feddema P, Leedman PJ, Brown SJ, O'Leary P (2010) Thyrotropin and thyroid antibodies as predictors of hypothyroidism: a 13-year, longitudinal study of a community-based cohort using immunoassay techniques. J Clin Endocrinol Metab 95:1095-1104

39. Irvine WJ, Davies SH, Delamore IW, Williams AW (1962) Immunological relationship between pernicious anemia and thyroid diseases. Brit Med J 2:454-456

40. Taylor KB, Roitt IM, Doniach D, Couchman KG, Shapland C (1962) Autoimmune phenomena in pernicious anemia: gastric antibodies. Br Med J 2:1347-1352

41. Mariotti S, Pisani S, Russova A, Bechi R, Giacomelli M, Passaleva A, Massai G, Baschieri L, Pinchera A (1984) A solid phase immunoradiometric assay for gastric parietal cell antibodies. Clin Exp Immunol 58:745-753

42. Karlsson FA, Burman P, Loof L, Olsson M, Scheynius A, Mardh S (1987) Enzyme-linked immunosorbent assay of $\mathrm{H}^{+}, \mathrm{K}^{+},-$ ATPase, the parietal cell antigen. Clin Exp Immunol 70:604-610

43. Strickland RG, Hooper B (1972) The parietal cell heteroantibody in human sera: prevalence in a normal population and relationship to parietal cell antibody. Pathology 4:259-263

44. Betterle C, Mazzi PA, Pedini B, Accordi F, Cecchetto A, Presotto F (1988) Complement-fixing gastric parietal cell autoantibodies: a good marker for the identification of type A chronic atrophic gastritis. Autoimmunity 1:267-274

45. Segni M, Borrelli O, Pucarelli I, Delle Fave G, Pasquino AM, Annibale B (2004) Early manifestations of gastric autoimmunity in patients with juvenile thyroid autoimmune diseases. J Clin Endocrinol Metab 89:4944-4948

46. Tozzoli R, Kodermaz G, Perosa AR, Tampoia M, Zucano A, Antico A, Bizzaro N (2010) Autoantibodies to parietal cells as predictors of atrophic body gastritis: a five-year prospective study in patients with autoimmune thyroid diseases. Autoim Rev 10:80-83

47. Bonifacio E, Lernmark $\AA$, Dawkins Rl et al (1988) Serum exchange and use of dilutions have improved precision of measurement of islet cell antibodies. J Immunol Methods 106:83-88

48. Bonifacio E, Boitard C, Gleichmann H, Shattock MA, Molenaar J, Bottazzo GF, Betterle C (1990) Assessment of precision, concordance, specificity, and sensitivity of islet cell antibodies measurement in 41 assays. Diabetologia 33:731-736

49. Greenbaum CJ, Palmer JP, Nagataki S, Yamaguchi Y, Molenaar JL, Wam Van Beers, Maclaren NK, Lernmak A (1992) Improved specificity of ICA assays in the Fourth International Immunology of Diabetes Serum Exchange Workshop. Diabetes 41:1570-1574

50. Palmer JP, Asplin CM, Clemons P, Lyen K, Tatpati O, Raghu PK, Paquette TL (1983) Insulin antibodies in insulin-dependent diabetics before insulin treatment. Science 222:1337-1339

51. Solimena M, Folli F, Denis-Donini S, Comi GC, Pozza G, De Camilli P, Vicari AM (1988) Autoantibodies to glutamic acid decarboxylase in a patient with stiff-man syndrome, epilepsy, and Type 1 diabetes mellitus. N Engl J Med 318:1012-1020

52. Rabin DU, Pleasic SM, Shapiro JA, Yoon-Warren H, Oles J, Hicks JM, Goldstein DE, Rae PMM (1994) Islet cell antigen 512 
is a diabetic-specific islet autoantigen related to protein tyrosine phosphatases. J Immunol 152:3183-3188

53. Lendrum R, Walker G, Gamble DR (1975) Islet-cell antibodies in juvenile diabetes mellitus of recent onset. Lancet $880-882$

54. Del Prete GF, Betterle C, Padovan D, Erle G, Toffolo A, Bersani $G$ (1977) Incidence and significance of islet-cell autoantibodies in different types of diabetes mellitus. Diabetes 26:909-915

55. Turner R, Stratton I, Horton V, Manley S, Zimmet P, Mackay IR, Shattock M, Bottazzo GF, Holman R (1997) UKPDS 25: autoantibodies to islet-cell cytoplasm and glutamic acid decarboxylase for prediction of insulin requirement in type 2 diabetes. UK Prospective Diabetes Study Group. Lancet 1:1288-1293

56. Slower RH, Eisenbarth G (1997) Prevention of type 1 diabetes and recurrent beta-cell destruction of transplanted Islets. Endocrine Rev 18:241-258

57. Betterle C, Spadaccino AC, Presotto F, Zanchetta R, Pedini B, Lai M, Greggio NA, Bottazzo GF (2002) The number of markers of pancreatic autoimmunity is proportional to the risk for type 1 diabetes mellitus (DM) in Italian and English patients with organspecific autoimmune diseases (OSAD). Ann N Y Acad Sci 958:276-280

58. Bottazzo GF, Lendrum R (1976) Separate autoantibodies to human pancreatic glucagon and somatostatin cells. Lancet 2:873-876

59. Betterle C, Zanette F, Presotto F, Pedini B, Tessari P, Valerio A, Tiengo A (1986) Alpha-cells autoantibodies: immunological and metabolic follow-up study. Horm Met Res 5:327-330

60. Blizzard RM, Kyle M (1963) Studies of the adrenal antigens and antibodies in Addison's disease. J Clin Invest 42:1653-1660

61. Betterle C, Coco G, Zanchetta R (2005) Adrenal cortex autoantibodies in subjects with normal adrenal function. Best Practice Res Clin Endocrinol Metab 19:85-99

62. Baumann-Antczak A, Wedlock N, Bednarek J, Kiso Y, Krishnan H, Fowler S, Rees Smith B, Furmaniak J (1992) Autoimmune Addison's disease and 21-hydroxylase. Lancet 340:429-430

63. Winqvist O, Karlsson FA, Kampe O (1992) 21-hydroxylase, a major autoantigen in idiopathic Addison's disease. Lancet 339:1559-1562

64. Colls J, Betterle C, Volpato M, Rees Smith B, Furmaniak J (1995) A new immunoprecipitation assay for autoantibodies to steroid 21-hydroxylase in Addison's disease. Clin Chem 41:375-380

65. Tanaka H, Perez MS, Powell M, Sanders JF, Sawicka J, Chen S, Prentice L, Asawa T, Betterle C, Volpato M, Rees Smith B, Furmaniak J (1997) Steroid 21-hydroxylase autoantibodies: measurements with a new immunoprecipitation assay. J Clin Endocrinol Metab 82:1440-1446

66. Betterle C, Volpato M, Pedini B, Chen S, Rees Smith B, Furmaniak J (1999) Adrenal-cortex autoantibodies and steroid producing cells autoantibodies in patients with Addison's disease: comparison of immunofluorescence and immunoprecipitation assays. J Clin Endocrinol Metab 84(2):618-622

67. Coco G, Dal Pra C, Presotto F, Albergoni MP, Canova C, Pedini B, Zanchetta R, Chen S, Furmaniak J, Rees Smith B, Mantero F, Betterle C (2006) Estimated risk for developing autoimmune Addison's disease in patients with adrenal cortex autoantibodies. J Clin Endocrinol Metab 91:1637-1645

68. Schopfer K, Matter L, Tenschert R, Bauer S, Zuppinger K (1984) Anti-glucagon-cell and anti-adrenal-medullary-cell antibodies in islet-cell-autoantibody positive diabetic children. N Engl J Med 310:1536-1537

69. Brown F, Smith AM, Longway S, Rabinowe SL (1990) Adrenal medullitis in Type 1 diabetes. J Clin Endocrinol Metab 71:1491-1495

70. Brown FM, Brink JS, Freeman R, Rabinowe SL (1989) Antisympathetic nervous system autoantibodies. Diminished catecholamines with orthostasis. Diabetes 38:938-941
71. Rabinowe SL (1990) Immunology of diabetic and polyglandular neuropathy. Diabetes/Metabolism Rev 6:169-188

72. Irvine WJ, Chan MMW, Scarth L (1968) Immunological aspects of premature ovarian failure associated with idiopathic Addison's disease. Lancet 2:886-887

73. Hoek A, Schoemaker J, Drexhage H (1997) Premature ovarian failure and ovarian autoimmunity. Endocrine Rev 18:107-134

74. Winqvist O, Gebre-Medhin G, Gustafsson J, Martin Ritzén E, Lundkvist O, Anders Karlsson F, Kämpe O (1995) Identification of the main gonadal autoantigens in patients with adrenal insufficiency and associated ovarian failure. J Clin Endocrinol Metab 80:1717-1723

75. Chen S, Sawicka J, Betterle C, Powell M, Prentice L, Volpato M, Rees Smith B, Furmaniak J (1996) Autoantibodies to steroidogenic enzymes in autoimmune polyglandular syndrome, Addison's disease, and premature ovarian failure. J Clin Endocrinol Metab 83:2977-2986

76. Reato G, Morlin L, Chen S, Furmaniak J, Rees-Smith B, Masiero S, Albergoni MP, Cervato S, Zanchetta R, Betterle C (2011) Premature ovarian failure in patients with autoimmune Addison's disease: clinical, genetic, and immunological evaluation. J Clin Endocrinol Metab 96:E1255-E1261

77. Blizzard RM, Chee D, Davis W (1966) The incidence of parathyroid and other antibodies in the sera of patients with idiopathic hypoparathyroidism. Clin Exp Immunol 1:119-128

78. Irvine WJ, Scarth L (1969) Antibody to the oxyphil cells of the human parathyroid in idiopathic hypoparathyroidism. Clin Exp Immunol 4:505-510

79. Posillico JT, Wortsman J, Sikanta S, Eisembarth GS, Mallette JW, Brown EM (1986) Parathyroid cell surface antibodies that inhibit parathyroid hormone secretion from dispersed human parathyroid cells. J Bone Miner Res 1:475-483

80. Brandi ML, Aurbach GD, Fattorossi A, Quarto R, Marx SJ, Fitzpatrick LA (1986) Antibodies cytotoxic to bovine parathyroid cells in autoimmune hypoparathyroidism. Proc Natl Acad Sci (USA) 83:8366-8369

81. Fattorossi A, Aurbach GD, Sakaguchi K (1988) Anti-endothelial cell antibodies: detection and characterization in sera from patients with autoimmune hypoparathyroidism. Proc Natl Acad Sci (USA) 85:4015-4019

82. Swana GT, Swana MR, Bottazzo GF, Doniach D (1977) A human specific mitochondria antibody: its importance in the identification of organ-specific reactions. Clin Exp Immunol 28:517-525

83. Betterle C, Caretto A, Zeviani M, Pedini B, Salviati G (1985) Demonstration and characterization of anti-human mitochondria autoantibodies in idiopathic hypoparathyroidism and in other conditions. Clin Exp Immunol 62:353-360

84. Li Y, Song YH, Rais N, Connor E, Schatz D, Muir A, Maclaren N (1996) Autoantibodies to the extracellular domain of the calcium sensing receptor in patients with acquired hypoparathyroidism. J Clin Invest 97:910-914

85. Goswami R, Brown EM, Kochupillai N, Gupta N, Rani R, Kifor O, Chattopadhyay N (2004) Prevalence of calcium sensing receptor autoantibodies in patients with sporadic idiopathic hypoparathyroidism. Eur J Endocrinol 150:9-18

86. Soderberg A, Myhre AG, Gebre-Medhin G, Hedstrand H, Landgren E, Miettinen A, Eskelin P, Halonen M, Tuomi T, Gustafsson J, Husebye ES, Perheentupa J, Gylling M, Manns MP, Rorsman F, Kampe O, Nilsson T (2004) Prevalence and clinical associations of 10 defined autoantibodies in autoimmune polyendocrine syndrome type I. J Clin Endocrinol Metab 89:557-562

87. Alimohammadi M, Björklund P, Hallgren A, Pöntynen N, Szinnai G, Shikama N, Keller MP, Ekwall O, Kinkel SA, Husebye ES, Gustafsson J, Rorsman F, Peltonen L, Betterle C, Perheentupa J, Akerström G, Westin G, Scott HS, Holländer GA, Kämpe O (2008) Autoimmune polyendocrine syndrome type 1 
and NALP5, a parathyroid autoantigen. $\mathrm{N}$ Engl $\mathrm{J}$ Med 358:1018-1028

88. Bottazzo GF, Pouplard A, Florin-Christensen A, Doniach D (1975) Autoantibodies to prolactin-secreting cells of human pituitary. Lancet 2:97-101

89. Caturegli P, Newschaffer C, Olivi A, Pomper MG, Burger PC, Rose NR (2005) Autoimmune hypophysitis. Endocrine Rev 26:599-614

90. Bellastella G, Rotondi M, Pane E, Dello Iacovo A, Pirali B, Dalla Mora L, Falorni A, Sinisi AG, Bizzarro A, Colao A, Chiovato L, De Bellis AM (2010) Predictive role of the immunostaining pattern of immunofluorescence and the titers of antipituitary antibodies at presentation for the occurrence of autoimmune hypopituitarism in patients with autoimmune polyendocrine syndromes over a five-year follow-up. J Clin Endocrinol Metab 95:3750-3757
91. Pouplard A, Bottazzo GF, Doniach D, Roitt IM (1976) Binding of human immunoglobulins to pituitary ACTH cells. Nature 13(261):142-144

92. Scherbaum WA, Bottazzo GF (1983) Autoantibodies to vasopressin cells in idiopathic diabetes insipidus: evidence for an autoimmune variant. Lancet 1:897-901

93. Scherbaum WA, Wass JAH, Besser GM, Bottazzo GF, Doniach D (1986) Autoimmune cranial diabetes insipidus: its association with other endocrine diseases and with histiocytosis X. Clin Endocrinol 25:411-420

94. Mackay IR (2010) Travels and travails of autoimmunity: a historical journey from discovery to rediscovery. Autoim Rev 9:A251-A258 